\title{
Hepatozoon pyramidumi sp. n. (Apicomplexa: Adeleorina) from the blood of Echis pyramidum: morphology and SSU rDNA sequence
}

\author{
Hepatozoon pyramidumi sp. n. (Apicomplexa: Adeleorina) do sangue de \\ Echis pyramidum: morfologia e sequência de SSU rDNA
}

\author{
Lamjed Mansour,2; Heba Mohamed Abdel-Haleem³; Esam Sharf Al-Malki; Saleh Al-Quraishy;
} Abdel-Azeem Shaban Abdel-Baki ${ }^{*}$ (1)

\author{
'Zoology Department, College of Science, King Saud University, Riyadh, Saudi Arabia \\ ${ }^{2}$ Unité de Recherche de Biologie Intégrative et Écologie Évolutive et Fonctionnelle des Milieux Aquatiques, Département de Biologie \\ Faculté des Sciences de Tunis, Université de Tunis El Manar, Tunisia \\ ${ }^{3}$ Zoology Department, Faculty of Science, Beni-Suef University, Beni-Suef, Egypt \\ ${ }^{4}$ Department of Biology, College of Sciences, Majmaah University, Majmaah 11952, Riyadh Region, Saudi Arabia
}

How to cite: Mansour L, Abdel-Haleem HM, Al-Malki ES, Al-Quraishy S, Abdel-Baki AZS. Hepatozoon pyramidumi sp. n. (Apicomplexa: Adeleorina) from the blood of Echis pyramidum: morphology and SSU rDNA sequence. Braz J Vet Parasitol 2020; 29 (2): e002420. https://doi.org/10.1590/S1984-29612020019

\begin{abstract}
Hepatozoon pyramidumi sp. n. is described from the blood of the Egyptian saw-scaled viper, Echis pyramidum, captured from Saudi Arabia. Five out of ten viper specimens examined (50\%) were found infected with Hepatozoon pyramidumi sp. n. with parasitaemia level ranged from 20-30\%. The infection was restricted only to the erythrocytes. Two morphologically different forms of intraerythrocytic stages were observed; small and mature gamonts. The small ganomt with average size of $10.7 \times 3.5 \mu \mathrm{m}$. Mature gamont was sausage-shaped with recurved poles measuring $16.3 \times 4.2 \mu \mathrm{m}$ in average size. Infected erythrocytes were hypertrophied; their nuclei were deformed and sometimes displaced from their central position in the normal uninfected cell. Merogonic stages were observed in the lung endothelial cell and the liver parenchyma cells. Mature meront was $17.8 \times 13.6 \mu \mathrm{m}$ and contained banana-shaped merozoites with average size of $\sim 15 \times 2 \mu \mathrm{m}$. Phylogenetic analysis based on the SSU rDNA sequence clustered Hepatozoon pyramidumi sp. $\mathrm{n}$ with previously sequenced Hepatozoon spp., most of them infected reptilian hosts without geographic consideration. The morphological and molecular comparison with closely related species proved the taxonomic uniqueness and novelty of the present form.
\end{abstract}

Keywords: Haemogregarine, snake, new species, phylogeny, Saudi Arabia.

\section{Resumo}

Hepatozoon pyramidumi sp. n. é descrito a partir do sangue da víbora em escamas e quilhas serrilhadas, Echis pyramidum, capturada na Arábia Saudita. Cinco de dez espécimes de víbora examinadas (50\%) foram encontradas infectadas com Hepatozoon pyramidumi sp. n. com nível de parasitemia de 20\% a 30\%. A infecção foi restrita apenas aos eritrócitos. Foram observadas duas formas morfologicamente diferentes de estágios intra-eritrocíticos: gamontes de tamanho pequeno e madura. As formas menores de gamontes apresentaram média de 10,7 ×3,5 $\mu \mathrm{m}$. Os gamontes maduros apresentaram forma de salsicha, com pequenos polos recurvados, medindo $16,3 \times 4,2 \mu \mathrm{m}$, em média. Os eritrócitos infectados estavam aumentados de tamanho; seus núcleos encontravam-se deformados e, algumas vezes, deslocados de sua posição central, quando comparados às células normais não-infectadas. Foram observados estágios merogônicos em células endoteliais pulmonares e nas células do parênquima hepático. Os merontes maduros apresentavam 17,8 ×13,6 $\mu \mathrm{m}$ e continham merozoítos em forma de banana com tamanho médio de $\sim 15 \times 2 \mu \mathrm{m}$. A análise filogenética baseada nas sequências SSU rDNA agrupou Hepatozoon pyramidumi sp. n com Hepatozoon spp. detectados em répteis de várias regiões geográficas. Por meio de análises morfológicas e moleculares com espécies intimamente relacionadas, demonstrou-se a singularidade dessa nova espécie de Hepatozoon.

Palavras-chave: Hemogregarine, cobra, novas espécie, filogenia, Arábia Saudita. 


\section{Introduction}

Genus Hepatozoon Miller 1908 is an assemblage of apicomplexan blood parasites that have been described from all members of vertebrates for more than a century. Hepatozoon has heteroxenous life cycles with merogonic and gamontogonic development within the vertebrate host, and gamogony and sporogony within the invertebrate host (Telford, 2009; Roca \& Galdón, 2010). Members of the genus Hepatozoon, along with those of genera Haemogregarina, Karyolysus, Cyrilia, Hemolivia and Desseria are collectively known as "haemogregarines" (Smith, 1996). All haemogregarines shared in the characteristic of gamontogonic development in either erythrocytes or leucocytes of their intermediate vertebrate hosts. Therefore, it is very difficult to identify the generic level based exclusively on the morphological characteristics of gamont stages (Abdel-Baki \& Al-Quraishy, 2012). Accordingly, Mihalca et al. (2002) suggested that the generic identification should be based on the characteristics of both gamont and sporogonic stages of its life cycle. Unfortunately, the complete life cycle and mode of transmission are lacking for the majority of haemogregarines (Abdel-Baki et al., 2014). In this regard, molecular techniques are notably helpful tools for both diagnostic and phylogenetic purposes and, as such, it has become firmly established to assign the accurate generic affiliation of haemogregarines (Abdel-Haleem et al., 2018). Using this attitude, here we tend to describe new species of Hepatozoon based on both the morphometry of gamont and merogonic stages, and the partial 18S rDNA sequence from the peripheral blood of Echis pyramidum collected from Saudi Arabia.

\section{Materials and Methods}

Ten Egyptian saw-scaled viper, Echis pyramidum (Geoffroy Saint-Hilaire, 1827) were collected from Jizan $\left(16^{\circ} 53^{\prime} 21^{\prime \prime} \mathrm{N} ; 42^{\circ} 32^{\prime} 3^{\prime \prime} \mathrm{E}\right),\left(29^{\circ} 22^{\prime} N 30^{\circ} 37^{\prime} \mathrm{E}\right)$, Saudi Arabia in Summer 2018. Thin blood smears were made by stab the tip of the tail of each viper then, were fixed with methanol and stained with Giemsa and finally microscopically examined for haemogregarine parasites. Two of highly infected vipers were dissected and small parts of lung, liver, spleen and kidney were excised and fixed in $10 \%$ of neutral buffered formalin. Fixed tissues were processed as usual for normal histology then, sectioned and stained with hematoxylin and eosin ( $\mathrm{H} \& \mathrm{E})$. The blood smears and histological sections were examined and photographed using an Olympus BX51 photomicroscope. Measurements were taken using calibrated ocular micrometer with an oil-immersion lens. All measurements are here given in micrometres; data are presented as mean \pm SD (when it possible) followed by rang in parentheses.

\section{Genetic characterization}

To genetically characterize the present haemogregarine, polymerase chain reaction (PCR) amplification using both the BTF1 (Megía-Palma et al., 2014) and the HEP1600R primers (Ujvari et al., 2004) was performed. The PCR protocol was as previously described by Abdel-Haleem et al. (2018). Briefly, 3ul were prepared by adding 50-100 ng of genomic DNA, $1 \mathrm{mM}$ of each primer, $1.5 \mathrm{mM} \mathrm{MgCl} 2,2 \mathrm{mM}$ of dNTPs and $0.5 \mathrm{U}$ of iProof ${ }^{\mathrm{TM}}$ High-Fidelity DNA (Bio-Rad, Hercules, CA, USA). For PCR amplification, after initial denaturation at $95^{\circ} \mathrm{C}$ for $4 \mathrm{mn}, 35$ cycles of three steps were performed $\left(96^{\circ} \mathrm{C}\right.$ for $20 \mathrm{~s}, 56^{\circ} \mathrm{C}$ for $20 \mathrm{~s}$ and $\left.72{ }^{\circ} \mathrm{C} 90 \mathrm{~s}\right)$. The program ends after final extension at $72{ }^{\circ} \mathrm{C}$ for $10 \mathrm{mn}$ ). A negative control was used for each reaction to check for possible DNA contamination. All PCR products were check by electrophoresis in 1\% gel agarose in TBE buffer $0.5 \mathrm{X}$ and stained with Ethidium bromide $0.5 \mu \mathrm{g} / \mathrm{mL}$ and visualized in UV-transilluminator workstation Gel Doc System (Biorad). The amplified PCR products were purified using A ExOSAP-ITTM (USB, Afymetrix) treatment and sequenced by an external commercial sequencing company (Macrogen Inc., Seoul, South Korea). The obtained sequence was assembled, and edited manually to resolve the ambiguous sites with aid of BioEdit version 7.2.5 (Hall, 1999). The generated sequence was compared with related published 18S rDNA sequences available in GenBank using the BLASTn program to confirm the generic identification and sequence was then submitted to GenBank (accession number: MT025290). For phylogenetic analysis, thirty sequences of Hepatozoon species in addition to sequences of Sarcocystis lacertae (used as an outgroup) were retrieved from GenBank to be used for multiple sequence alignment using ClustalX 2.1.0.12 software (Larkin et al., 2007) with default parameters. Both of Maximum likelihood (ML) and Bayesian inference (BI) were utilized for phylogenetic analyses. For generating of ML trees; the General Time Reversible model with gamma-distributed rates was employed and invariant sites (GTR + I + G) estimated using jModelTest 2.1.1 (Darriba et al., 2012). Constructing the consensus tree was carried out in the software MEGA version 7 (Kumar et al., 2016). Bootstrap technique, with 1,000 replicates was employed to estimate the support for nodes. The evolutionary relationships between sequences were assessed using Kimura 2-parameter model (Kimura, 1980). The BI was accomplished using Mr-Bayes v3.2.5 program (Ronquist et al., 2012). The analysis was run for $2 \times 10^{6}$ generations with one tree saved every 100 generations. The posterior probability of the trees was determined utilizing Metropolis-Coupled 
Markov Chain Monte Carlo $(M C M C)$ algorithm running four chains (nchains $=4)$. In every Bayesian run, the first $25 \%$ of the saved trees were discarded as burn-in prior to reaching stationary. The consensus tree was constructed with an average standard deviation of split frequencies of 0.008 .

\section{Results}

Out of 10 snakes examined, 5 were found positive for haemogregarines with an overall prevalence of (50\%). The parasitaemia level (number of infected erythrocytes per 1000 examined) in the infected snakes ranged from 20-30\%.

\section{Blood stages}

Microscopic examination of the prepared blood smears revealed that only erythrocytes were infected with stages of previously undescribed haemogregarines (Figure 1). Leucocytes appeared free of infection. Of the intraerythrocytic stages, two morphologically different forms were recognized; small and mature forms of gamonts. The small form occurred individually in the erythrocytes with average size of $10.7 \pm 0.2(10-12) \mu \mathrm{m}$ in length and $3.5 \pm 0.3(3-4) \mu \mathrm{m}$ in width (Figures 1A, 1B). The prominent nucleus of the small form was faintly stained, occupied most of the cytoplasm and measured $6.4 \pm 0.4(5-7) \times 3 \pm 0.2(2-3)$ (Figures 1A, 1B). The mature form of gamont was the most common form seen in the blood smears (Figure 1). Gamont was sausage-shaped with eccentric deeply stained nucleus and small recurved poles and sometimes enclosed within a parasitophorous vacuole (Figures 1B, 1C). Gamont measured $16.3 \pm 0.6(16-18) \mu \mathrm{m}$ in length and $4.2 \pm 0.4(4-5) \mu \mathrm{m}$ in width while the size of its nucleus was $6.8 \pm 0.5(6-8) \times 2.8 \pm 0.7$ (2-3) (Figures 1D, 1E). Infrequently, extracellular or free moving gamonts were also noticed within the examined smears. (Figure 1A), As well as single erythrocytes infected by two gamonts either embracing the host cell nucleus or with different positions regarding the host cell nucleus were observed (Figures 1D, 1E). The average size of uninfected erythrocytes was $16.2 \pm 1.2(14-18) \times 9 \pm 0.5(8-10) \mu \mathrm{m}$ while the size of their nuclei was $8 \pm 0.5$ (7-9) $\times 5 \pm 0.4$ (4-5) $\mu \mathrm{m}$. Infected erythrocytes were hypertrophied particularly in multiple infections; their nuclei were deformed and sometimes displaced from their central position in the normal uninfected cell (Figure 1). The measurements of the infected cells were $21.8 \pm 1.6(20-24) \times 11.3 \pm 1.3(10-13) \mu \mathrm{m}$ while the dimensions of its nuclei were $9.8 \pm 0.8(8-11) \times 3.2 \pm 0.7(3-4) \mu \mathrm{m}$.

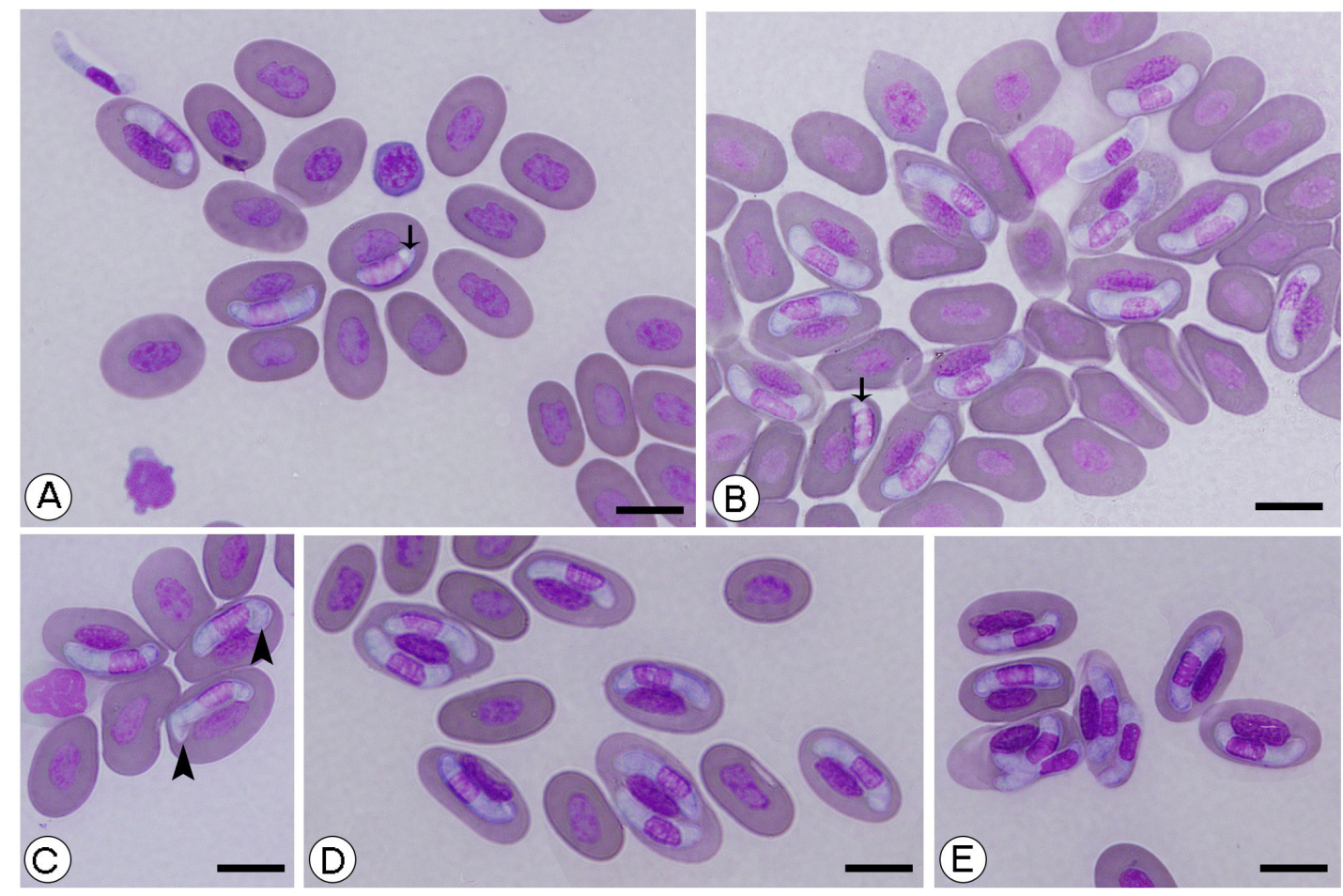

Figure 1. Giemsa stained blood stages of Hepatozoon pyramidumi sp. n. in the peripheral blood of Echis pyramidum. Arrows in (A) and (B) refer to the small form of gamont while arrowheads in (C) refer to the recurved poles of gamonts. Observe the free gamont in (A) and the double infection in (D) and (E). Scale-bar $=10 \mu \mathrm{m}$. 


\section{Tissue stages}

Histological examinations elucidated that the merogony with merogonic stages at different phases of development occurred both in lung and liver of the infected hosts (Figure 2). As the parasite invaded the lung endothelial cell and the liver parenchyma, a parasitoporous vacuole appeared enclosing the meront. The earliest detectable stage was a multinucleated meront which is spherical in shape and measured $\sim 16.8(16-18) \mu \mathrm{m}$ wide (Figure 2A). Meronts grew in size to $21.7(20-23) \times 13.2(12-14) \mu \mathrm{m}$ (Figures 2B-D). The nuclei of meront ordinarily divided several times, producing larger multinucleated meront with periphery arranged nuclei attaining the size of $29.2(28-31) \times 18.2(17-21) \mu \mathrm{m}$ (Figure 2E). Mature meronts dimensions were $17.8(16-20) \times 13.6(13-15) \mu \mathrm{m}$. Mature merozoites were banana in shape with average size of $\sim 15 \mu \mathrm{m}$ in length and $2 \mu \mathrm{m}$ in width (Figure $2 \mathrm{~F}$ ). Sometimes filtrated erythrocytes containing gamonts were observed in the liver tissue Figure 2G).
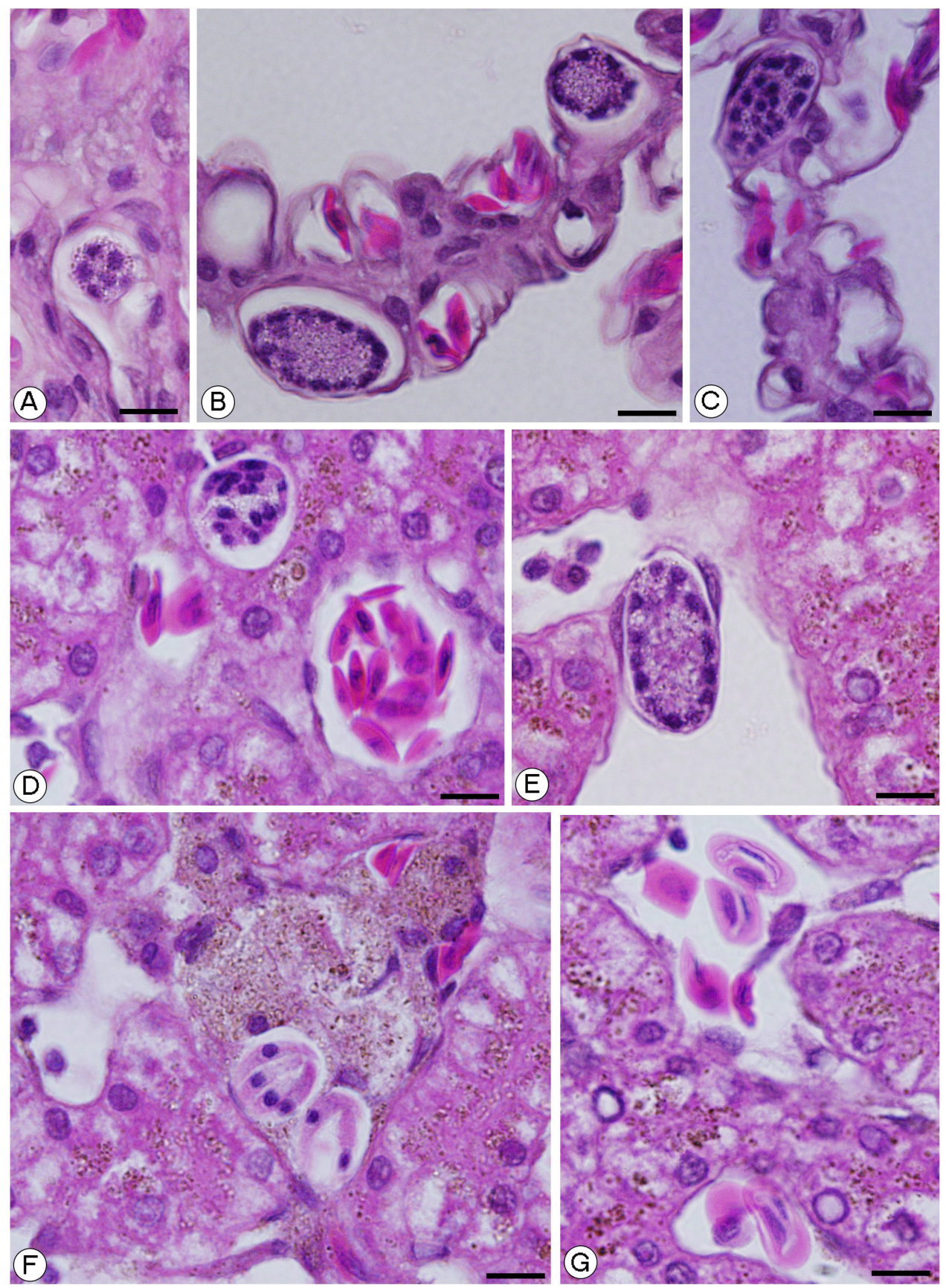

Figure 2. Histological investigation of Hepatozoon pyramidumi sp. n. merogonic stages in the liver and lung of Echis pyramidum. (A), (D), (E) Multinucleated meronts at different phases of development in the liver; (B), (C) Multinucleated meronts at different phases of development in the lung; (F) Mature meronts with well-defined merozoites; $(G)$ Observe the filtrated erythrocytes containing gamonts in the liver tissue. $\mathrm{H} \& \mathrm{E}$ stain, Scale-bar $=10 \mu \mathrm{m}$. 


\section{Molecular and phylogenetic study}

A consensus partial sequence of 1389 bp of the SSU rRNA was generated and deposited in GenBank (accession number MT025290). The BLAST results of the obtained sequence displayed nucleotide sequence similarities ranged from 93.34 to $99.7 \%$ with other known Hepatozoon sequences from various geographic localities. The highest sequence identity of $99.7 \%$ was to an unnamed Hepatozoon sp. (GenBank entry KJ574012) parasite of Cerastes cerastes from Egypt and Hepatozoon sp. (GenBank entry HQ734790) parasite of Ptyodactylus oudrii from Algeria. Phylogenetic based on maximum likelihood and Bayesian inference, yielded a similar topology and cluster H. pyramidumi tree with other Hepatozoon from various geographic area but most of them infect reptilian hosts. Outside this main cluster, two other clusters were observed, one grouping Hepatozoon spp. from mammals and the second one grouping Hepatozoon spp. infecting amphibian host (Figure 3).

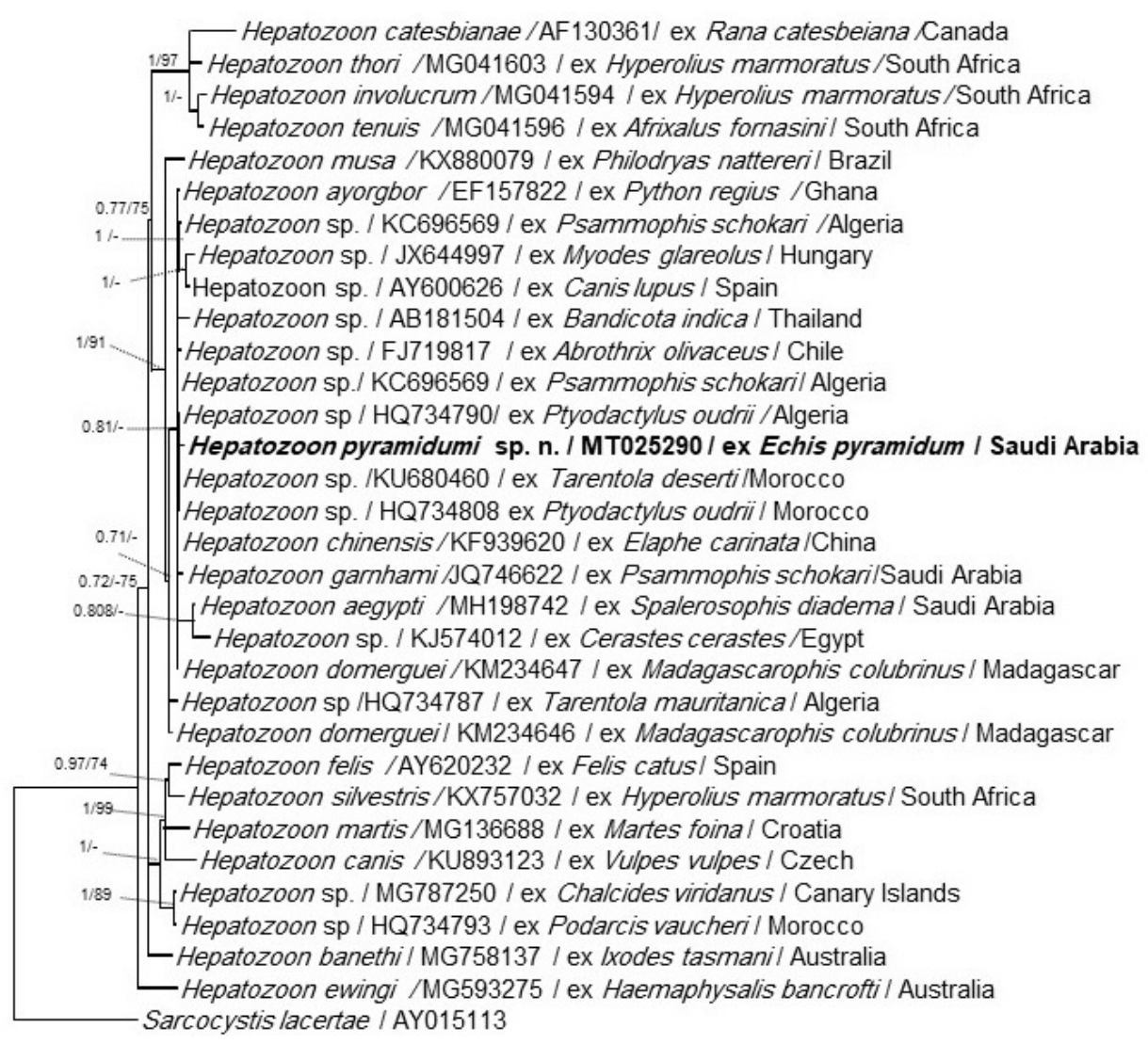

Figure 3. Bayesian inference tree topology based on SSU rDNA of Hepatozoon sequences showing the position of Hepatozoon pyramidumi sp. $\mathrm{n}$.. Numbers at nodes = Bayesian posterior probabilities /maximum likelihood bootstrap support. Dashes indicate nodes with support $<0.8 / 50 \%$, or not present in the maximum likelihood tree. GenBank accession numbers and geographic locality are beside taxon names.

\section{Taxonomic summary}

Type host: Echis pyramidum (Ophidia, Viperidae).

Other hosts: Unknown.

Type locality: Jizan (1653' 21" N; 42³2' 3" E), Saudi Arabia.

Site of infection: Gamonts in the erythrocytes and merogonic stages in the lung endothelial cells and the liver parenchyma cells.

Vector: Unknown.

Prevalence: 50\% (5/10).

Type-material: Two slides with blood smears are deposited at the Museum of the Zoology Department, College of Science, King Saud University, Saudi Arabia (Hep 01-2020).

Sequence accession numbers: MT025290.

Etymology: The specific epithet is given after the host name. 


\section{Discussion}

Haemogregarines are diversified group of intracellular apicomplexan parasites that are known to infect a wide variety of vertebrate hosts. For a long time, the identification of haemogregarine species was principally based solely on morphological and/or biological features of gamont stages in erythrocytes of the host (Perkins \& Keller, 2001). However, morphological comparison alone is not quite enough for distinguishing the closely related species, because of the low host specificity and pliability of gamonts morphology (Telford, 2010; Harris et al., 2011). More recently, molecular approach together with morphological data are strongly suggested as prerequisite for differential diagnoses and taxonomy of haemogregarines (O'Donoghue, 2017). Within hemogregarines, Hepatozoon is the most commonly described and the most speciose genus (Harris et al., 2018). Snakes have been proven worldwide as hosts of more than 145 Hepatozoon species (Úngari et al., 2018). However most of these species descriptions were primarily based alone on the morphology of the intraerythrocytic gamont, as the life cycle and mode of transmission of these parasites were unidentified (Tomé et al., 2016; Abdel-Haleem et al., 2018). Currently, molecular attitudes based on $18 \mathrm{~S}$ rRNA gene sequence variations became extremely helpful complementary tool for differentiating the closely related species of the genus Hepatozoon (Maia et al., 2016; Tomé et al., 2016). Consequently, it is become widely accepted that the morphological characteristics of intraerythrocytic stages combined with the molecular are quite enough to establish the novelty the Hepatozoon species (Abdel-Haleem et al., 2018). In present study, therefore, H. pyramidumi sp. n. was identified through morphological comparison to Hepatozoon spp. of similar host genus and locality and to species that are phylogenetically assembled in the same clade. So far, two species of Hepatozoon have been described from snakes of the genus Echis. These species are: $\mathrm{H}$. echisi described from saw-scaled viper Echis carinatus in West Pakistan (Mohiuddin et al., 1967) and H. mehlhorni described from the same host (E. carinatus) in western Egypt (Bashtar et al., 1991). H. echisi easily differentiate from the present species in having shorter and thinner gamonts $(13.97 \times 2.8$ vs. $16.3 \times 4.2)$. As well as the Merogony of $H$. echisi was restricted to lung endothelial cells while the present species occurred in both lung endothelial cells and liver parenchyma. Meanwhile, H. mehlhorni differs in having larger gamont $(17.2 \times 5.4$ vs $16.3 \times 4.2)$ and dimorphic meronts. The merogonic pattern of $H$. mehlhorni is also different, with meronts apparently dimorphic producing up to 38 merozoites measuring $6 \times 1.5 \mu \mathrm{m}$ in size compared to monomorphic meronts producing up to 15 merozoites $15 \times 2 \mu \mathrm{m}$ in the present species. Phylogenetic tree analysis revealed that the $18 \mathrm{~S}$ rRNA sequences of $E$. pyramidum clustered together with Hepatozoon spp. from reptiles (Figure 3). Hepatozoon pyramidumi n. sp. showed highest sequence identity (99.7\%) to Hepatozoon sp. (KJ574012) and Hepatozoon sp. (HQ734790) which still unidentified to the species level and with no available morphological data that precluded the further morphological comparison. Of the other clustered species; the morphological and morphometric data are available only for $\mathrm{H}$. domerguei Landau, Chabaud, Michel, Brygoo, 1970 from Madagascarophis colubrinus in Madagascar, H. garnhami Abdel-Baki, Al-Quraishy, Zhang, 2014 from Psammophis schokari in Saudi Arabia, H. chinensis Han, Wu, Dong, Zhu, Li, Zhao, Wu, Pei, Wang, Huang, 2015 from Elaphe carinata in China and H. aegypti Bashtar, Boulos, Mehlhorn, 1984 from Spalerosophis diadema in Egypt which give the opportunity for further comparison (Maia et al., 2014; Abdel-Baki et al., 2014; Han et al., 2015; Abdel-Haleem et al., 2018). In this regard, H. domerguei differs in having shorter and thinner encapsulated gamonts $(13.8 \times 3$ vs $16.3 \times 4.2)$. In addition, the merogonic cycle of $H$. domerguei produce dimorphic meronts compared to monomorphic ones in the present species. H. garnhami can be easily differentiated from the present species by its quite thinner gamonts (2 vs 4.2) and its merogonic cycle that was restricted to lung with dimorphic meronts. In the same way, the thinner gamonts that was folded back in a hook-wise at one end separated $H$. chinensis from the present species. Finally, H. aegypti differs in having shorter gamonts (14 vs 16.3) with merogonic cycle apparently restricted to the endothelial cells of lung.

These morphometric comparisons clearly distinguished the species investigated here from the closely related ones. As well as molecular data confirmed the classification of the present Hepatozoon as a new species.

\section{Acknowledgements}

This work was supported by Researcher supporting Project (RSP-2019/3), King Saud University.

\section{References}

Abdel-Baki AA, Al-Quraishy S. Morphological characteristics of a new species of Haemogregarina Danilewsky, 1885 (Apicomplexa: Adeleorina) in naturally infected Acanthodactylus boskianus (Daudin) (Sauria: Lacertidae) in Egypt. Syst Parasito/ 2012; 82(1): 65-69. http://dx.doi.org/10.1007/s11230-012-9347-x. PMid:22488433. 
Abdel-Baki AA, Al-Quraishy S, Zhang JY. Redescription of Haemogregarina garnhami (Apicomplexa: Adeleorina) from the blood of Psammophis schokari (Serpentes: Colubridae) as Hepatozoon garnhami n. comb. based on molecular, morphometric and morphologic characters. Acta Parasitol 2014; 59(2): 294-300. http://dx.doi.org/10.2478/s11686-014-0241-3. PMid:24827101.

Abdel-Haleem HM, Mansour L, Holal M, Qasem MA, Al-Quraishy S, Abdel-Baki AS. Molecular characterisation of Hepatozoon aegypti Bashtar, Boulos \& Mehlhorn, 1984 parasitising the blood of Spalerosophis diadema (Serpentes: colubridae). Parasitol Res 2018; 117(10): 3119-3125. http://dx.doi.org/10.1007/s00436-018-6006-4. PMid:30022290.

Bashtar AR, Abdel-Ghaffar FA, Shazly MA. Life cycle of Hepatozoon meh/horni sp. nov. in the viper Echis carinatus and the mosquito Culex pipiens. Parasitol Res 1991; 77(5): 402-410. http://dx.doi.org/10.1007/BF00931635. PMid:1891449.

Darriba D, Taboada GL, Doallo R, Posada D. jModelTest 2: more models, new heuristics and parallel computing. Nat Methods 2012; 9(8): 772. http://dx.doi.org/10.1038/nmeth.2109. PMid:22847109.

Hall TA. BioEdit: A user-friendly biological sequence alignment editor and analysis program for windows 95/98/NT. Nucleic Acids Symp Ser 1999; 41: 95-98.

Han H, Wu Y, Dong H, Zhu S, Li L, Zhao Q, et al. First report of Hepatozoon (Apicomplexa: Adeleorina) from king ratsnakes (Elaphe carinata) in Shanghai, with description of a new species. Acta Parasito/ 2015; 60(2): 266-274. http://dx.doi.org/10.1515/ap-20150038. PMid:26203995.

Harris DJ, Halajian A, Santos JL, Swanepoel LH, Taylor PJ, Xavier R. Diversity of haemoprotozoan parasites infecting the wildlife of South Africa. Folia Parasitol 2018; 65: 15. PMid:30348909.

Harris DJ, Maia JP, Perera A. Molecular characterization of Hepatozoon species in reptiles from the Seychelles. J Parasitol 2011; 97(1): 106-110. http://dx.doi.org/10.1645/GE-2470.1. PMid:21348615.

Kimura M. A simple method for estimating evolutionary rates of base substitutions through comparative studies of nucleotide sequences. J Mol Evol 1980; 16(2): 111-120. http://dx.doi.org/10.1007/BF01731581. PMid:7463489.

Kumar S, Stecher G, Tamura K. MEGA7: Molecular Evolutionary Genetics Analysis version 7.0 for bigger datasets. Mol Biol Evol 2016; 33(7): 1870-1874. http://dx.doi.org/10.1093/molbev/msw054. PMid:27004904.

Larkin EK, Morris NJ, Li Y, Nock NL, Stein CM. Comparison of affected sibling-pair linkage methods to identify gene x gene interaction in GAW15 simulated data. BMC Proc 2007;1(Suppl 1): S66. http://dx.doi.org/10.1186/1753-6561-1-S1-S66. PMid:18466567.

Maia JP, Carranza S, Harris DJ. Comments on the systematic revision of adeleid haemogregarines: are more data needed? J Parasitol 2016; 102(5): 549-552. http://dx.doi.org/10.1645/15-930. PMid:27385057.

Maia JP, Crottini A, Harris DJ. Microscopic and molecular characterization of Hepatozoon domerguei (Apicomplexa) and Foleyella furcata (Nematoda) in wild endemic reptiles from Madagascar. Parasite 2014; 21: 47. http://dx.doi.org/10.1051/parasite/2014046. PMid:25224723.

Megía-Palma R, Martínez J, Merino S. Molecular characterization of haemococcidia genus Schellackia (Apicomplexa) reveals the polyphyletic origin of the family Lankesterellidae. Zoo/ Scr 2014; 43(3): 304-312. http://dx.doi.org/10.1111/zsc.12050.

Mihalca AD, Achelăriţei D, Popescu P. Haemoparasites of the genus Haemogregarina in a population of European pond turtles (Emys orbicularis) from Drăgăşani, Vâlcea county, Romania. Rev Sci Parasitol 2002; 2: 22-27.

Mohiuddin A, Pal RA, Warsi AA. Haemogregarina echisi n. sp. from the saw-scaled viper Echis carinatus of the Sind Region of West Pakistan. J Protozool 1967; 14(2): 255-259. http://dx.doi.org/10.1111/j.1550-7408.1967.tb01993.x.

O'Donoghue P. Haemoprotozoa: making biological sense of molecular phylogenies. Int J Parasitol Parasites Wildl 2017; 6(3): 241 256. http://dx.doi.org/10.1016/j.ijppaw.2017.08.007. PMid:28913164.

Perkins SL, Keller AK. Phylogeny of nuclear small subunit rRNA genes of hemogregarines amplified with specific primers.J Parasitol 2001; 87(4): 870-876. http://dx.doi.org/10.1645/0022-3395(2001)087[0870:PONSSR]2.0.CO;2. PMid:11534653.

Roca V, Galdón MA. Haemogregarine blood parasites in the lizards Podarcis bocagei (Seoane) and P. carbonelli (Pérez-Mellado) (Sauria: Lacertidae) from NW Portugal. Syst Parasitol 2010; 75(1): 75-79. http://dx.doi.org/10.1007/s11230-009-9206-6. PMid:20012520.

Ronquist F, Teslenko M, van der Mark P, Ayres DL, Darling A, Höhna S, et al. MrBayes 3.2: efficient Bayesian phylogenetic inference and model choice across a large model space. Syst Bio/ 2012; 61(3): 539-542. http://dx.doi.org/10.1093/sysbio/sys029. PMid:22357727.

Smith TG. The genus Hepatozoon (Apicomplexa: adeleina). J Parasitol 1996; 82(4): 565-585. http://dx.doi.org/10.2307/3283781. PMid:8691364.

Telford SR Jr. Hemoparasites of the Reptilia: color atlas and text. Boca Raton: CRC Press; 2009. 
Telford SR Jr. Three new Hepatozoon species (Apicomplexa: Hepatozoidae) infecting the Florida kingsnake, Lampropeltis getula floridana. J Parasitol 2010; 96(1): 162-169. http://dx.doi.org/10.1645/GE-2161.1. PMid:19685939.

Tomé B, Rato C, Harris DJ, Perera A. High diversity of Hepatozoon spp. in geckos of the genus Tarentola. J Parasitol 2016; 102(4): 476-480. http://dx.doi.org/10.1645/15-908. PMid:26835601.

Ujvari B, Madsen T, Olsson M. High prevalence of Hepatozoon spp. (Apicomplexa, Hepatozoidae) infection in water pythons (Liasis fuscus) from tropical Australia. J Parasito/ 2004; 90(3): 670-672. http://dx.doi.org/10.1645/GE-204R. PMid:15270125.

Úngari LP, Santos ALQ, O'Dwyer LH, Silva MRL, Santos TCR, Cunha MJR, et al. Molecular characterization and identification of Hepatozoon species Miller, 1908 (Apicomplexa: Adeleina: Hepatozoidae) in captive snakes from Brazil. Parasitol Res 2018; 117(12): 3857-3865. http://dx.doi.org/10.1007/s00436-018-6092-3. PMid:30267181. 